\title{
Trans theoretical Model in Seminar and Hands-on of Cross-Infection Prevention Effort by Creative Dental Hygienists
}

\author{
Ida Ayu Dewi Kumala Ratih ${ }^{1}$, Maria Martina Nahak ${ }^{2}$, Muhammad Saleh ${ }^{3}$, I Made Budi Artawa ${ }^{4}$ \\ Lecturer, Department of Dental Hygienist, Poltekkes Kemenkes Denpasar, Bali, Indonesia ${ }^{1,2,4}$ \\ Lecturer, Department of Dental Hygienist, Poltekkes Kemenkes Makassar, South Sulawesi, Indonesia ${ }^{3}$
}

\begin{abstract}
Dental Health Services in Indonesia is also done by non-certified independent dental workers who is lack of coaching and supervision of the authorities, resulting in not optimal sterilization of tools that can lead to the emergence of other diseases/abnormalities, so that preventive infections in them is needed to get attention. The aim of research is to understand the effectiveness of giving seminars and practices on the efforts to prevent cross infection in non-certified independent dental workers by creative dental health workers with Transtheoretical model in City of Denpasarand Makassar, Indonesia. This type of research is a quasi-experimental with Nonrandomized Pre-test post-test model with a control group design. Large samples are all non-certified independent dental workers in the city of Denpasar and Makassar. The research data were analysed using descriptive tests which were performed by different test between groups using the Wilcoxon test. The creativity of dental health workers measurement was done by ManWhitney test.Based on the analysis and discussion, it is concluded that giving treatment in form of seminar and handson are proven to increase knowledge of non-certified independent dental workersin Denpasar is higher than that in Makassar. Behaviour changes in infection protection efforts is undertaken by knowledge. The efforts made by highly creative dental nurses in Denpasar, proved successful in changing the behaviour of non-certified independent dental workers into a stage of change, rather than creative dental nurses in Makassar.
\end{abstract}

KEYWORDS: Hands-on, Cross-infection prevention, Creative dental hygienists.

\section{INTRODUCTION}

Dental and oral health services are not only done by dentists and dental therapists, but some are done by the noncertified independent dental workers. Based on policy of Indonesia specifically Permenkes RI No. 339/Menkes/Per/V/1989, the non-certified dental workers is a person who does work in the field of healing and restoring dental health and has no education based on dentistry and has had permission from the Minister of Health [1][2].

The Results of the survey conducted by the general manager of the Indonesian Dentist Association (PBPDGI) in 2016 showed that the weak enforcement and lack of coaching and supervision from the authorities in this case is local government and health office, leads to an illegal practice of the non-certified dental workers and the emergence of various negative impacts due to the practice of the non-certified dental workers[3]. Adverse effects that could arise other diseases/disorders due to incorrect treatment, transmission of diseases caused by not knowing or deliberately do not perform prevention. Some diseases could be transmitted through the practice of dentistry are: Hepatitis, HIV/AIDS, and sexually transmitted diseases that have manifested in the oral cavity e.g. syphilis, tuberculosis, herpes and fungal infections[4].

In carrying out the duties and functions, dental workers must have the knowledge and skills in accordance with the qualifications required by the law and is expected to behave properly in preventing cross infection in the practice room. For that dental hygiene in this case, dental hygienist are expected to have creative strength, in monitoring and evaluating the performance of the non-certified dental workers, so that the dentist continues to get a science renewal especially in the field of cross-infection prevention. One or a group of people who changes behavior and continue to do so sustainably to optimize health can be measured using transtheoritical models[5]. In transtheoritical model, changes are interpreted as a developmental processes that take place in a while and through the six stages called the stage of change[6].

Based on preliminary study, it was obtained that the dental workers do not only serve the creation of a loose dentures as perthe law mandate. Based on the authors' observation in Denpasar City, Bali Province and the Makassar City, South Sulawesi province, the non-certified dental workers who call themselves as a dentist, are increasingly popping up and 


\author{
||Volume 9, Issue 6, June 2020\|
}

attracting people. People seem to do not care about their safety. The aim of this research is to understand the effectiveness of seminar and hands-onof the cross-infections prevention efforts of the non-certified independent dental workers by the Creative Dental Hygienistusing the approach of transtheoretical model.

\title{
II. RELATED WORK
}

The concept of transtheoretical model or also known as TTM is that a framework about behaviour in health changes which go through six stages of process, i.e. precontemplation, contemplation, preparation, action, maintenance and last is termination[7-12]. TTM has adapted in the studies of smoking cessation. The study aimed to test the validity and reliability of TTM based questionnaire for smoking cessation. It was done using crosssectional validation. In TTM itself, there should be several instruments to measure what extent interventions could make changes in people's behaviour. This research used Cronbach's alpha which resulted in satisfactory finding, besides it is appropriate, reliable and valid[13]. Another application of TTM is used for sedentary behaviour. The subject was college students aimed to understand their motivational readiness to avoid sedentary behaviour. The TTM instrument was questionnaires based on TTM constructs. Its result is quite different that there is a high proportion of college students were in sedentary stages regardless physical activity levels in men and women distribution[14]. In dental health itself, TTM also functions to promote behaviour changes and provide guidance to recognize dental behaviour change which can be one of intervention program[15]. Transtheoretical model has also done to school students using cross-sectional study. Some instruments used were interdental cleaning behaviour, decisional balance and self-efficacy. The result shows that TTM does meaningful behaviour change[16-18]. TTM has also practiced in clinics for dental patients[19][20]. Yet, TTM for non-certified dental workers are still few. Thus, this research was done using transtheoretical model for non-certified dental workers as it it's needed to give them accompaniment so that all their services are standardized.

\section{METHODOLOGY}

This research is a quasi experiment with the design of One Group pretest-posttest to measure the level of knowledge and skills of the non-certified dental workers, while to recognize the creativity of dental hygienists, it was used posttest only without control Group design. The population in the study was all the non-certified dental workers who opens practice in Denpasar and Makassar city in 2018. Large samples were determined with a large sample formula[21], namely: 96.04, then the number of samples is as many as 96 people and is divided into 2 treatment groups namely 48 people in the city of Denpasar and 48 people in the city of Makassar randomly selected. The samples in Denpasar were given treatment with seminar and hands-on about preventing cross-infections in the dental practice while the control group in the city of Makassar received the treatment of leaflets on preventing cross infections in the practice of noncertified dental workers. During the study both in Denpasar and Makassar, there are samples that drop out, so the number of samples were obtained as much as 80, namely 40 non-certified dental workers in Denpasar and 40 in Makassar.

\section{EXPERIMENTAL RESULTS}

Table 1 shows Mann-Whitney test results for comparison of knowledge pretests value between non-certified dental workers in Denpasar and Makassar City about cross infection prevention before Seminar and Hands-on as well as Leaflet were given.

Table 1. Comparison of knowledge pre-test in Denpasar and Makassar

\begin{tabular}{|c|c|c|c|c|c|c|c|c|c|}
\hline \multirow{2}{*}{ No. } & \multirow{2}{*}{ Knowledge level } & \multicolumn{2}{|c|}{$\begin{array}{l}\text { Pretest in } \\
\text { Denpasar }\end{array}$} & \multicolumn{2}{|c|}{$\begin{array}{l}\text { Pretest in } \\
\text { Makassar }\end{array}$} & \multicolumn{2}{|c|}{ Mean Rank } & \multirow{2}{*}{$\mathrm{Z}$} & \multirow{2}{*}{ Q } \\
\hline & & $\mathrm{F}$ & $\%$ & $\mathrm{~F}$ & $\%$ & $\begin{array}{l}\text { Pretest in } \\
\text { Denpasar }\end{array}$ & $\begin{array}{l}\text { Pretest in } \\
\text { Makassar }\end{array}$ & & \\
\hline 1. & Excellent & 37 & 92.5 & 8 & 20 & & & & \\
\hline 2. & Good & 2 & 5 & 12 & 30 & & & & \\
\hline 3. & Fair & 1 & 2.5 & 17 & 42.5 & 57.88 & 23.13 & -6.749 & 0.000 \\
\hline 4. & $\mathrm{Bad}$ & 0 & 0 & 2 & 5 & & & & \\
\hline 5. & Failed & 0 & 0 & 1 & 2.5 & & & & \\
\hline
\end{tabular}


Information can be taken based on table 1 is that the comparative value of the pre-test knowledge of cross infections in Denpasar is higher in rank compared to Makassar, and the Mann Whitney test results indicate that the difference is significant at the value of $\mathrm{p}=0,000(\mathrm{p}<0.05)$.

Mann-Whitney test results to determine the comparison of the knowledge post-test value between dentists in Denpasar and Makassar regarding cross infection prevention after the Seminar and Hands on and leaflet division are shown in table 2.

Table 2. Comparison of knowledge pre-test in Denpasar and Makassar

\begin{tabular}{|c|c|c|c|c|c|c|c|c|c|}
\hline \multirow[b]{2}{*}{ No } & \multirow[b]{2}{*}{ Knowledge level } & \multicolumn{2}{|c|}{$\begin{array}{c}\text { Post-test } \\
\text { in Denpasar }\end{array}$} & \multicolumn{2}{|c|}{$\begin{array}{c}\text { Post-test in } \\
\text { Makassar }\end{array}$} & \multicolumn{2}{|c|}{ Mean Rank } & \multirow[b]{2}{*}{$\mathrm{Z}$} & \multirow[b]{2}{*}{ Q } \\
\hline & & $\mathrm{F}$ & $\%$ & $\mathrm{~F}$ & $\%$ & $\begin{array}{c}\text { Pot-test } \\
\text { in } \\
\text { Denpasar }\end{array}$ & $\begin{array}{l}\text { Post-test } \\
\text { in } \\
\text { Makassar }\end{array}$ & & \\
\hline 1 & Excellent & 40 & 100 & 37 & 92.5 & & & & \\
\hline 2 & Good & 0 & 0 & 3 & 7.5 & & & & \\
\hline 3 & Fair & 0 & 0 & 0 & 0 & 56.39 & 24.61 & $\begin{array}{l}- \\
6.309\end{array}$ & 0.000 \\
\hline 4 & $\mathrm{Bad}$ & 0 & 0 & 0 & 0 & & & & \\
\hline 5 & Failed & 0 & 0 & 0 & 0 & & & & \\
\hline
\end{tabular}

Table 2 above shows that the comparison of post-test knowledge of the cross-infection in which Denpasar has higher rate in rank compared to Makassar, and the difference is significant at the value $p=0,000(p<0.05)$.

Friedman test result to find out the difference in the observation of the dentist behaviour by the Creative Dental Hygienists in Denpasar and Makassar City can be seen in Table 3.

Table 3. Friedman Test of behaviour observation on non-certified dental workers

\begin{tabular}{|c|c|c|c|c|c|c|c|}
\hline \multirow[b]{2}{*}{ City } & \multirow[b]{2}{*}{ Observation } & \multirow[b]{2}{*}{ Mean } & \multirow[b]{2}{*}{ SD } & \multicolumn{4}{|c|}{ Friedman Test Results } \\
\hline & & & & $\begin{array}{l}\text { Mean } \\
\text { Rank }\end{array}$ & df & $X^{2}$ & $\mathrm{P}$ \\
\hline \multirow[t]{3}{*}{ Denpasar } & 1 & 10.50 & 3.922 & 1.44 & \multirow{3}{*}{2} & & \\
\hline & 2 & 12.92 & 3.654 & 2.16 & & 33.521 & 0.000 \\
\hline & 3 & 13.55 & 3.928 & 2.40 & & & \\
\hline & & & & & & & \\
\hline \multirow[t]{3}{*}{ Makassar } & 1 & 7.67 & 2.955 & 1.13 & \multirow{3}{*}{2} & & \\
\hline & 2 & 10.80 & 2.884 & 2.36 & & 57.535 & 0.000 \\
\hline & 3 & 11.22 & 2.566 & 2.51 & & & \\
\hline
\end{tabular}

Table 3 represents a meaningful difference between the first and third observation results of the dentist behavior etiher in Denpasar or Makassar City, with the difference is significant at the value $p=0,000(p<0.05)$.

In accordance to frequency distribution of respondents' response to creativity of dental hygienists in Denpasar and Makassar are measured by some creative abilities namely; Dental hygienists have a great curiosity, about the efforts of cross-infection prevention by non-certified dental workers, Dental hygienists think about new approaches that can be used to improve Quality of Service, Dental hygienists have a new approach to accelerating the process of changing the dentist behavior in a cross-infection prevention, Dental hygienists have confidence, the success of crossinfection prevention efforts by non-certified dental workers, Dental hygienists work diligently to achieve goals and Dental hygienist present in the midst of employees when they are experiencing difficulties. Based on the observation, it was concluded that mostly, the respondents of non-certified dental workers assessed the dental hygienists in Denpasar is very creative with score of 127 in degree of "Strongly Agree" among others, specifically in the indicator of new approach to accelerate behavior changes of non-certified dental workers.

The results of the study can prove that there is a meaningful difference between the level of knowledge on the prevention of cross infections of the dentists in Denpasar before and after getting seminar and Hands-on, with a confidence level smaller than 0.005, which is 0.0345. Besides, the pre-test value resulted in mostly,non-certified dental workers in Denpasar are with excellent criteria, no one has level of knowledge with bad or failed criteria, the post test results show the whole non-certified dental workers has a level of knowledge with excellent criteria. Furthermore, the results of the research in the city of Makassar also showed almost the same thing in Denpasar, yet the results of the most pre-test (42.5\%) in Makassar have a level of knowledge with fair criteria, and only one (1) person has a failed 


\author{
\|Volume 9, Issue 6, June 2020\|
}

level of knowledge, this can happen probably because most of the non-certified dental workers in Makassar is roving dental workers in markets. At the post-test, there is a meaningful change (with a confidence level of 0.000) after receiving treatment with only given the leaflet. The value of pretests knowledge on cross infections in Denpasar's noncertified dental workers is higher in rank compared to Makassar. The comparison of post-test value in Denpasar is higher in rank compared with the city of Makassar significantly.Transtheoritical Model (TTM) is an integrative model that explains in the early stages of behavioral change, people involve cognitive, affective and evaluative processes to aidself- development or achieve gradual progression[22]. Bygiving seminar and hands-on, meaning that the noncertified dental workers gain experience in preventing cross-infections, in accordance with the opinion of Edgar Dale's communication Experts with the coneof experience theory that to achieve the optimum results of the learning process, one of the things that is highly recommended is the use of media, directly in the form of real or reality objects. The learning process and teaching interactions are not only fromdirect experience, but can begin with the type of experience that best fits the needs and abilities of audience groups taking into consideration the learning situation, so that the learning process become more effective and efficient[23].

The Results of research analysis show that there is a meaningful difference between the results of observation to one (1) to three (3) to the behavior of the dentist in the effort to prevent cross infections in Denpasar and Makassar city, with significance value of $0.000(\mathrm{p}<0.05)$. Assessment of behavior through first observation after getting seminar and hands on in Denpasar obtained the most $(57.5 \%)$ is at the Contemplation stage, where the non-certified dental workers intend to make a cross-infection prevention efforts in the next month. In addition, there is only $1 \%$ in the Maintenance stage, that the respondent has made efforts to prevent cross infections by hand washing, wearing masks, applying alcohol, and spreading the tool with sterilizers, the rest is the Preparation and Action, no-Termination stage, furthermore, at the third observation, respondents have been reminded about the correct behavior, so there is no longer respondent on the Precontemplation stage. The behavior of respondents has changed to the next phase of the Contemplation, even only 6 respondents were at this stage, because within a month most of the respondents had been in the Action stage in as much as 21 people (52.5\%), Maintenance stage were occupied by two people (5\%), no Termination stage. This is made possible because respondents have had knowledge of the prevention of good cross infections, the experience of respondents, the information obtained, so that the respondent had sterilized more than six months ago, this is in line with the research results of [6][24].

While the results of the behavioral analysis of dentists in Makassar in the first observation (1) shows the majority of respondents $(55 \%)$ also categorized in the stage of contemplation where the respondent has no intention to make a preventive effort against cross infection, hasn't be able yet to do, most of the respondents are the roving noncertified dental workers around the traditional market, most respondents do not have dental units. There are no respondents at the pre-contemplation and termination stages. After the three-time observation, where dental hygiene has reminded and trained the respondents, their behavior changes, only $22.5 \%$ (nine respondents) are still at this stage, most of them are in the preparation stage, partly at the action stage, even there is a meaningful changes in as much as four people who are at the stage of maintenance, this means that the dental workers has undergone a change in behavior, although hasn't yet be in termination stage, since it takes a longer time to perform monitoring and treatment.

The results of research analysis proved that dental hygienists who were observing, guiding the non-certified dental workers about cross infection prevention is a very creative dental health worker, where the respondent gave a Strongly Agree Assessment (5), which means they are very creative. On the indicator which has a new approach to accelerate the process of changing the dentist behavior in the prevention of cross infections, the results is that they have a great curiosity and work diligently. Yet a slightly different valuation of the respondents in Makassar, most respondents assessed dental hygienist is as a person who has creative ability, by rating it on Agree (4), which means creative. There are respondents who rate Unable to Judge(3), which means enough and thereis also an indicator of dental hygienists' presence in the middle of the non-certified dental workers when they are having trouble.

Creative Dental Hygienists in this case addressed to dental hygiene workers is a dental health worker who has a variable dimension of creativity itself, so that they are able to conduct coaching and supervision to the non-certified dental workers sustainably. By the creative ability owned by dental health workers, it is expected that they will acquire a special knowledge about the preventive efforts of cross infections, so that it can change the behavior of the noncertified dental workers to realize the dental health for society. Creative Dental hygienists are dental care that has a great curiosity and thinking about a new in guiding the non-certified dental workers as well as accelerating the process of behavioral change, having confidence, working diligently, and attending the middle of a handyman to help overcome difficulties[25].

Factors that influence behavior According to Green in [26]determined by three factors, namely: 1) predisposing factor, this factor is influenced by people's knowledge and attitudes towards health, traditions and society towards matters relating to health, people faith in community, education, socioeconomic level and so on. 2) supporting factor, this factor approves facilities and infrastructure or health facilities for the community, 3) reinforcing factors, the 


\author{
||Volume 9, Issue 6, June 2020\|
}

community sometimes not only requires knowledge and positive attitude and fulfillment of facilities only to behave healthy, but also help as examples ( reference) by health workers.

Analysis shows that changes of attitude on cross-infection prevention among non-certified dental workers are influenced by knowledge of respondents in either before and after the seminar, hands-on as well as leaflet were given. Not to mention, explanations for observation and assistance, as set out in Table 2 for respondents in Denpasar which show that most of them have a very good level of knowledge and all respondents have a very good level of knowledge. Table 3 for respondents in Makassar shows that most of them had fair and good level of knowledge at the time of the pre-test, but it changes to $92.5 \%$, meaning that respondents have a very good level of knowledge, none of which had fair, bad or failed level of knowledge.

Another factor influencing changes in the behavior of non-certified dental workers in efforts to prevent crossinfection is the Stage of Change stage at the time of observation for the first time, as for respondents in Denpasar, it is known that most of them (23\%) are in the Contemplation, Preparation, Action, and only $1 \%$ at the Maintenance stage. Furthermore, the third observation, respondents were reminded of the correct behavior, then respondents who were at the Pre-contemplation stage changed their behavior to the next stage, which is the Contemplation stage, even only 6 respondents were at this stage, because within one month most of the respondents had been at the Action stage, 21 people $(52.5 \%)$. While the results of the behavior analysis of non-certified dental workers in Makassar on the first observation (1) show that the majority of respondents $(55 \%)$ were also in the Contemplation stage, where most of the respondents were roving dental workers around the traditional markets. There were no respondents at the Precontemplation and Termination stages. After observing for the third time, the behavior of the respondents changed, only $22.5 \%$ (nine respondents) were still at this stage, most of the non-certified dental workers were at the Preparation stage, some at the Action stage, even significant changes were found in four persons who were in the Maintenance stage.

Efforts made by Creative Dental Hygienists both in Denpasar and Makassar proved to be successful in changing the behavior of dental workers. This can be achieved because the Dental Hygienist has a new approach to accelerate the process of changing behavior of dental workers to prevent cross infection, have a great curiosity, and work diligently. The Dental Hygienist always pays attention to the initial stages of observation, and subsequent observations which must monitor and evaluate the progress of respondents' behavior.

\title{
V. CONCLUSION
}

Seminar and hands-on intervention conducted on respondents in Denpasar city proved to increase knowledge of non-certified dental workers higher than that given only leaflets to respondents in Makassar.The treatment group in Denpasar has better stage of change than that in Makassar group, most of the Denpasar respondents were in the Action stage, while the group in Makassar was mostly in the Preparation stage. The Denpasar treatment group was considered to be very creative in carrying out efforts to prevent cross-infection, a slightly different assessment of respondents in Makassar, most respondents rated it as a creative Dental Hygienists. Changes in behaviour regarding effort to prevent cross infection are influenced by knowledge, Stage of Change at the time of observation for the first time, then the efforts made by highly creative dental hygienist in Denpasar as well as creative dental hygienist have proven successful in changing the behaviour of dental workers to the betterment of stage of change.

\section{REFERENCES}

[1] W. S. F. Pinasthika, "Perlindungan Hukum Terhadap Konsumen Penerima Layanan Ortodonti oleh Tukang Gigi Berdasarkan Hukum Perlindungan Konsumen dan Hukum Kesehatan,” Universitas Indonesia, 2012.

[2] R. Kennedy, "Perlindungan Konsumen Terhadap Jasa Pelayanan oleh Tukang Gigi ditinjau dari UndangUndang No 8 Tahun 1999 tentang Perlindungan Konsumen,” Universitas Lampung, 2014.

[3] F. Hanum, "Pelayanan Kesehatan Gigi di Indonesia, Sebuah Realita," PBPDGI, Jakarta, 04-Mar-2017.

[4] S. Mulyanti and M. H. Putri, Pengendalian Infeksi Silang di Klinik Gigi. Jakarta: EGC, 2011.

[5] S. A. Shumaker, E. B. Schron, J. K. Ockene, and W. L. McBee, The Handbook of Health Behavior Change. Springer Publishing Co, 1998.

[6] J. O. Prochaska and W. F. Velicer, "The Transtheoretical Model of Health Behavior Change," PubMed, vol. 13, pp. 38-48, 1997.

[7] J. O. Prochaska and W. F. Velicer, "The Transtheoretical Model of Health Behavior Change," Sci. Heal. Promot., vol. 12, no. 1, pp. 38-48, 1997.

[8] M. Hashemzadeh, A. Rahimi, F. Zare-Farashbandi, A. A. Mansur, and A. Daei, "Transtheoretical Model of Health Behavioral Change: A Systematic Review," Iran. J. Nurs. Midwifery Res., vol. 24, pp. 83-90, 2019.

[9] S. Kang and Y. Kim, "Application of the transtheoretical model to identify predictors of physical activity 
transition in university students," J. Sport Psychol., vol. 26, no. 3, pp. 6-11, 2017.

[10] J. B. Kolbert, B. L. Happe, D. Hyatt-burkhart, and L. M. Crothers, "Motivational Interviewing, the Transtheoretical Model of Change, and Academic Development," J. Sch. Couns., vol. 15, no. 7, 2017.

[11] D. M. P. Diltz and C. J. Yeager, "Application of the Transtheoretical Model Within the Integrative Developmental Model of Supervision," in Association for Counselor Education and Supervision Conference, 2004, pp. 103-114.

[12] M. Friman, J. Huck, and L. E. Olsson, "Transtheoretical Model of Change during Travel Behavior Interventions : An Integrative Review,” Int. J. Environ. Res. Public Health, vol. 14, no. 581, pp. 1-15, 2017.

[13] F. Sarbandi, S. Niknami, A. Hidarnia, E. Hajizadeh, and A. Montazeri, "The transtheoretical model ( TTM ) questionnaire for smoking cessation : psychometric properties of the Iranian version," BioMed Cent., vol. 13, no. 1186 , pp. 1-6, 2013.

[14] H. Han, K. P. Gabriel, and H. W. Kohl, "Application of the transtheoretical model to sedentary behaviors and its association with physical activity status," PLoS One, vol. 12, no. 4, pp. 1-13, 2017.

[15] D. Setyowati, "The transtheoretical model : A basis for changing dental behaviour to improve oral health," $J$. PDGI, vol. 60, no. 1, pp. 24-28, 2011.

[16] M. Ali and M. Arezoo, "Interdental Cleaning Behaviour and Its Relationship with Psychological Constructs Based on the Transtheoretical Model," Oral Heal. Prev. Dent., vol. 9, no. 3, pp. 211-220, 2011.

[17] B. N. Shahrbabaki, M. Hashemian, A. Fallahi, and A. Rahmani, "The Relationship between Stages of Dental Cleaning Behavior Change Based on Trans-theoretical Model ( TTM ) with School Role and Social Support in Students," Int J Pediatr, vol. 5, no. 41, pp. 4939-4949, 2017.

[18] T. Kamalikhah, S. M. M. Abad, N. Khalighinejad, and F. R. Najarkolaei, "Dental flossing behaviour and its determinants among students in a suburb area of Tehran-Iran: using Transtheoretical Model," Int. J. Dent. Hyg., vol. 5, no. 2, 2015.

[19] K. J. Wade, D. E. Coates, R. D. C. Gauld, V. Livingstone, and M. P. Cullinan, "Oral hygiene behaviours and readiness to change using the TransTheoretical Model (TTM)," N Z Dent J, vol. 109, no. 2, pp. 64-68, 2013.

[20] S. Emani, R. Thomas, R. Shah, and D. S. Mehta, "Application of transtheoretical model to assess the compliance of chronic periodontitis patients to periodontal therapy," Contemp. Clin. Dent., vol. 7, no. 2, pp. 176-181, 2016.

[21] S. Lemeshow, D. W. H. Jr, J. Klar, and S. K. Lwanga, Adequacy of Sample Size in Health Studies. World Health Organization, 1997.

[22] S. A. Shumaker, J. K. Ockene, and K. A. Riekert, The handbook of health behavior change, 3rd ed., 3rd ed. Springer Publishing Company, 2009.

[23] A. H. Sequeira, "Introduction to Concepts of Teaching and Learning," SSRN Electron. J., 2012.

[24] C. B. Nawangpalupi, L. Pratiwi, and Y. Herawati, "Evaluasi Perubahan Pola Konsumsi Dengan Menggunakan Model Stages Of Change : Studi Kasus Pengurangan Penggunaan Kantung Plastik Belanja,” Res. Report- Eng. Sci., vol. 1, 2010.

[25] R. Jain and P. Sharma, "Creative Abilities of Indian Managers and Blocks to Creativity Enhancement: An Empirical Study," Manag. Labour Stud., vol. 37, no. 1, pp. 1-16, 2012.

[26] Notoatmodjo, Promosi Kesehatan dan Ilmu Perilaku. Jakarta: Rineka Cipta, 2007. 